Online social media - a vehicle for city branding in China: The case of Sponge City Program (SCP)

Dimple Thadani, Lei Li, Faith Ka Shun Chan

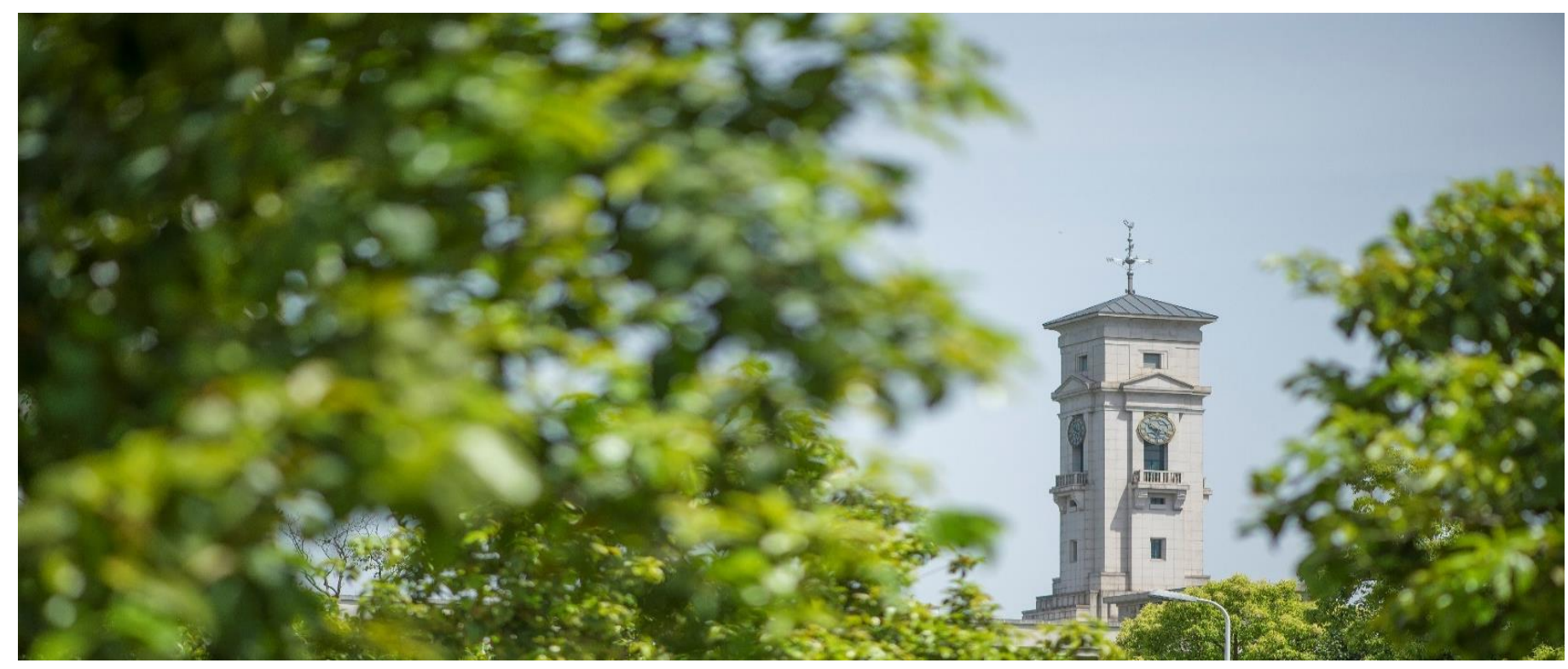


University of Nottingham Ningbo China, 199 Taikang East Road, Ningbo, 315100, Zhejiang, China.

First published 2020

This work is made available under the terms of the Creative Commons Attribution 4.0 International License:

http://creativecommons.org/licenses/by/4.0

The work is licenced to the University of Nottingham Ningbo China under the Global University Publication Licence:

https://www.nottingham.edu.cn/en/library/documents/research/global -university-publications-licence-2.0.pdf 


\title{
Online Social Media - A Vehicle for City Branding in China: The Case of Sponge City Program (SCP)
}

\author{
Dimple Thadani ${ }^{1}$, Lei $\mathrm{Li}^{2}$, and Faith Ka Shun Chan ${ }^{2,3,4}$ \\ ${ }^{1}$ Nottingham University Business School, University of Nottingham Ningbo China, Ningbo \\ 315100, China \\ ${ }^{2}$ School of Geographical Sciences, Faculty of Science and Engineering, University of Notting- \\ ham Ningbo China, Ningbo 315100, China \\ ${ }^{3}$ School of Geography, University of Leeds, Leeds LS2 9JT, UK \\ ${ }^{4}$ Water@Leeds Research Institute, University of Leeds, LS2 9JT, UK \\ Dimple.thadani@nottingham.edu.cn \\ Faith.Chanenottingham.edu.cn
}

\begin{abstract}
The shift of academic attention from city marketing to city branding heralds a new era of representation and signification of cities as brands. Conscious practices of nationwide program implementation could be used not only for urban resilience improvement but also for city brands promotion. In China, to cope with the frequent occurrence of urban floods and droughts, a nationwide initiative called Sponge City Program (SCP) has been launched since 2013. Given the tremendous impact of online social media on brand image, various levels of the Chinese Governments have begun to use online social media for city program promotion. In particular, brand community formed by stakeholders on online social media can significantly influence the brand image by co-creating contents. In this paper, we first analyze the current application of online social media for city marketing in China based on the case of SCP implementation. Next, we propose a framework/typology to inform how Chinese' social media could be used for effective city branding. Finally, we provide a conclusion by discussing the implications of online social media use in China
\end{abstract}

Keywords: Sponge City Program, City Branding, Online Social Media, Urban Water Management

\section{Introduction}

The rise of globalization and its consequent urban planning restructuration have been accompanied by cutthroat intercity competition $[11,12,27]$. The accent of financialization - capturing investments and capitals- has made city marketing and city branding integral strategies for competitiveness development and sustainable urban growth [8]. The shift of attention from city marketing to city branding heralds a new era of representation and signification of cities as brands. In this perspective, "city, as the object of branding, becomes of locus of value, embedded in social practices and situated in a 
spatial location" [3] (p. 148). Positive city branding is regarded as economic and social instruments to enhance city's welfare [13].Although effective city branding is a prolonged management process, conscious practices of nationwide urban program implementation (e.g. utilizing appropriate communication channels) facilitates city brands promotion.

In China, to cope with the frequent occurrence of urban floods and droughts, a nationwide initiative called Sponge City Program (SCP) has been launched since 2013. Community acceptance and financial challenges are considered to be the strongest barriers against the adoption and implementation of SCP [21]. Public-private partnership is one of the best way to make the program viable [14,37], which could be achieved via city marketing and branding. Given the tremendous impact of online social media on brand image, various levels of the Chinese Governments have begun to use online social media for city program promotion. In particular, brand community formed by stakeholders on online social media could significantly influence the brand image by co-creating contents.

The goal of this article is twofold: First, we analyze the current application of online social media for city marketing in China based on the case of SCP implementation. Then, we propose a framework/typology to inform how Chinese' social media could be used for effective city branding. Implications on online social media use in China are discussed.

\section{Current Application of Online Social Media: The Case of SCP Implementation}

\subsection{City Marketing and City Branding}

Cutthroat competition among cities motivates city government to utilize marketing and branding strategies for city promotion. City marketing is a process of planning and promoting cities to satisfy the needs of city target markets [9,17-19]. The main entities in city marketing implementation are local government, organizations and residents $[4,9,25]$. City brand is considered to be one of the essential city products $[9,17,25,38]$ that provides a conscious and reliable commitment to stakeholders (i.e. local government, residents and organizations) in enhancing city images [31,36,38]. City branding can thus be considered as one of the city marketing strategies to strengthen long term relationships between a city and its stakeholders so as to establish good city image [17]. Specifically, city branding is process of identity building in which geographical, social, and cultural attributes are integrated $[31,36,38]$, and thrives as a means for promoting competitive advantages [2]. Utilizing online social media for city marketing and city branding have been applied in various context [e.g. 23,32,34,35] including nationwide program implementation. 


\subsection{Online Social Media}

With rapid propagation of online social media, webs/apps users including the government, organizations and city residences can easily create and disseminate media content. Hence, online social media plays an important role in shaping public perceptions and attitude [6] which impacts community acceptance and financial resources for nationwide program implementation. In particular, online social media is broadly defined as online technologies and platforms that allow users to connect, communicate, and interact with each other, often by posting, sharing, or co-producing information online [7]. Different typologies of online social media depending on their type and characteristics have been proposed by prior researchers [e.g.20,29]. The most widely used online social media typology was proposed by Kaplan and Haenlein [16] based on two dimensions : the degree of social presence/ media richness, and self-presentation/ self-disclosure. Table 1 summarizes the six types of online social media with global examples.

Table 1. Six Types of Online Social Media [16]

\begin{tabular}{|c|c|c|}
\hline Type of Online Social Media & Descriptions & Examples \\
\hline 1. Collaborative Projects & $\begin{array}{l}\text { Platforms that allow users to add, remove, } \\
\text { and change text-based content. }\end{array}$ & Wikipedia \\
\hline 2. Blogs and Micro-blogs & $\begin{array}{l}\text { Platforms that come in a } \\
\text { multitude of different variations, from per- } \\
\text { sonal diaries describing the author's life to } \\
\text { summaries of all relevant information in } \\
\text { one specific content area. }\end{array}$ & Twitter; Weibo \\
\hline 3. Content Communities & $\begin{array}{l}\text { Platforms that aim at sharing content } \\
\text { among users including news site. }\end{array}$ & Youtube; Youku \\
\hline 4. Social Networking Services & $\begin{array}{l}\text { Platforms that aim at connecting users by } \\
\text { creating personal profiles. }\end{array}$ & $\begin{array}{l}\text { Facebook; } \\
\text { WeChat }\end{array}$ \\
\hline 5. Virtual Game Worlds & $\begin{array}{l}\text { Platforms that replicates three dimensional } \\
\text { environment in which users can appear in } \\
\text { the form of avatars or virtual characters } \\
\text { with game rules restricting the range of in- } \\
\text { teractions }\end{array}$ & $\begin{array}{l}\text { World of } \\
\text { Warcraft }\end{array}$ \\
\hline 6. Virtual Social Worlds & $\begin{array}{l}\text { Platforms that replicates three dimensional } \\
\text { environment in which users can appear in } \\
\text { the form of avatars or virtual characters, } \\
\text { but no rules restricting the range of possi- } \\
\text { ble interactions }\end{array}$ & Second Life \\
\hline
\end{tabular}


Stockmann and Luo [30] classified Chinese cyberspace according to two dimensions social interaction and information sharing, and suggested that patterns of public opinion is different for different type of online social media. For instance, the twitter-like Weibo offers users the power to become the source of information, including individual, organizations and the government. Baidu Tieba is a BBS-like chat forum with an average of 50 million new post per day. Indeed, the emergence of online media has provided the government with more opportunities to better communicate with the public. Previous studies have addressed the role of online media in terms of government transparency and interactivity [10,26,28]. It is believed social media could be an effective vehicle for city marketing and city branding [39].

\subsection{Online Social Media for City Marketing in the Current SCP Implementation}

In the past, the only active entity in city marketing and branding is the city government [25]. City program promotion was often done via traditional media such as TV advertisement and magazines. These traditional promotion approaches are high in operation cost and lack feedback from the audience. Effective city marketing implementation needs multi-directional interactions between the city government, organizations and city residents. The contemporary online social media channel provides a bilateral beneficial vehicle for mutual communication between city's stakeholders because of its participative, interactive and ubiquitous nature [23,32,34,35]. Given the benefits of online social media, various levels of the Chinese Governments have begun to utilize online social media for city program promotion. In this article, we are focusing on the use of social media for one of the nationally significant program of urban water management- The Sponge City Program (SCP).

In China, a nationwide initiative called Sponge City Program (SCP), intended to improve urban water management [5], has been launched since 2015. Rapid urbanization, coupled with global climate changes, has recently caused severed urban floods and other water issues in Chinese cities [15]. In response, the SCP strategy was put forward by the Chinese National Government in 2013, intended to increase urban resilience in adapting to environmental changes and dealing with disasters caused by water. SCP integrates a new urban planning and development mode [5,22], which envisions Chinese cities copes with sustainable water systems that operates like a sponge to absorb, store, purify and release urban stormwater spontaneously [24].

\section{The Current Online Social Media Use for SCP Implementation in China}

To understand the current application of online social media for nationwide program promotion in China, we have done a systematic search by identifying SCP related articles published in online social media between 2013 and 2019. We followed the guidelines provided by Webster and Watson [33] to identify relevant articles. Given the variety of terminology describing SCP, we based the articles search on a range of Chinese and English keywords including "Sponge City", "Sponge City Program”, "SCP”, “海 
绵城市” using Baidu and google search engines. In addition, the top 5 most popularly international and Chinese online social media were manually searched.

The initial searches returned 1651 articles in total. Following the guidelines of the systematic review methodology, we applied inclusion and exclusion criteria to the initial set of articles. The inclusion criteria were (1) SCP was the main focus of investigation and comments; (2) The article was written in Chinese or English; (3) article published between 2013 and 2019. The exclusion criteria were applied to (1) articles in which SCP was referenced merely as the main topic; (2) duplicate or linguistically unusable articles; (3) photos or videos without SCP related hashtags. 890 articles were excluded from analysis because they failed to meet the criteria stipulated in the current research design. At the end of the review and screening process, 418 articles published between 2013 and 2019 were identified.

\section{Preliminary Findings}

418 SCP articles published on online social media between 2013 and 2019 were identified at the end of the review and screening process. Table 2 provides an overview of the number of SCP articles by year and online social media outlet categorized using Kaplan and Haenlein [16] typology.

Table 2. Online Social Media Outlets for SCP Articles

\begin{tabular}{|c|c|c|c|c|c|c|c|c|}
\hline Online Social Media Outlets & Total & 2019 & 2018 & 2017 & 2016 & 2015 & 2014 & 2013 \\
\hline \multicolumn{9}{|l|}{ Content Communities } \\
\hline $\begin{array}{l}\text { - News website (e.g. Sina } \\
\text { News; Business insiders; } \\
\text { Wechat News) }\end{array}$ & 377 & 68 & 65 & 90 & 99 & 54 & 1 & 0 \\
\hline $\begin{array}{l}\text { Dynamic video/audio } \\
\text { community (e.g. Tiktok, } \\
\text { Youku, Voice tube 影音 } \\
\text { 號) }\end{array}$ & 30 & 13 & 10 & 6 & 1 & 0 & 0 & 0 \\
\hline Blogs and Micro-blogs (e.g. Weibo) & 9 & 3 & 4 & 2 & 0 & 0 & 0 & 0 \\
\hline $\begin{array}{l}\text { Social Networking Services (e.g. } \\
\text { WeChat) }\end{array}$ & 2 & 2 & 0 & 0 & 0 & 0 & 0 & 0 \\
\hline Total & 418 & 86 & 79 & 98 & 100 & 54 & 1 & $\mathbf{0}$ \\
\hline
\end{tabular}

Referring to table 2, SCP articles first appeared in news website (i.e., WeChat News) in 2014, and majority of these articles (90\%) were found to publish in news websites. Surprisingly, among the 407 published articles in the content communities, only 63 of them specified City information; and only 27 of these articles were involved in the interactivity activities (e.g. forwarded/ liked /commented). SCP articles first published on video/audio community in 2015 , and has been steadily increasing ever since. 


\section{Framework of Chinese Social Media for City Branding}

Although it is believed that online social media could be an effective vehicle for city marketing and city branding [39], our preliminary findings suggest that the current SCP implementation have not fully utilized the interactive and participative nature of online social media. Majority of SCP articles were published in static news websites with emphasizes on technical content which made them difficult to be commented. Among all these news websites, $95 \%$ of interactive actions such as forwarding, commenting and liking were done on Chinese SCP articles. More importantly, there is a lack of two-way communications between the city government, organizations and city resident, which are considered to be essential components of city branding. Recognizing that interactivity, source of information, and media richness are important dimensions that could facilitate city branding, we propose the following framework by integrating typologies suggested by Kaplan and Haenlein [16] and Stockmann and Luo [30].

The first dimension relates to the degree to which individual users/ organization/ government users disseminate information on the social media platform. The second dimension relates to the degree to which the functions of the platform support two-way interactions between users. The third dimensions relates to the degree of media richness provided by the platform. The top 5 most popular Chinese social media platforms in 2019 [1] are mapped onto a three-dimensional construct of online social media as shown in Fig. 1.

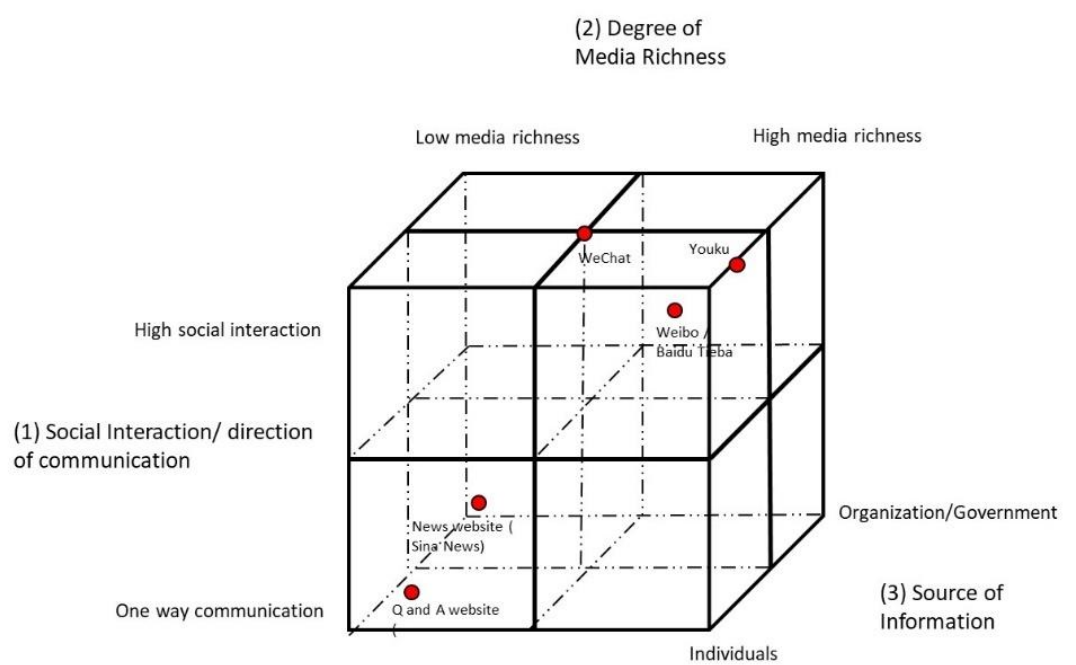

Fig. 1. The three-dimensional mapping of various Chinese online social media

Although city government has been using online media that enhances the openness and transparency of city marketing and branding, it remains a government-lead market- 
ing approach that lacks interaction and participation from other stakeholders. In addition, from our preliminary results, we found that Chinese SCP articles published on Chinese online social media received far more attention from the audiences than those published in non-Chinese social media. Thus, we believe that we should put more focus on utilizing these Chinese oriented social media platforms. Fig 2. Suggests a roadmap for future online social media use for SCP implementation.

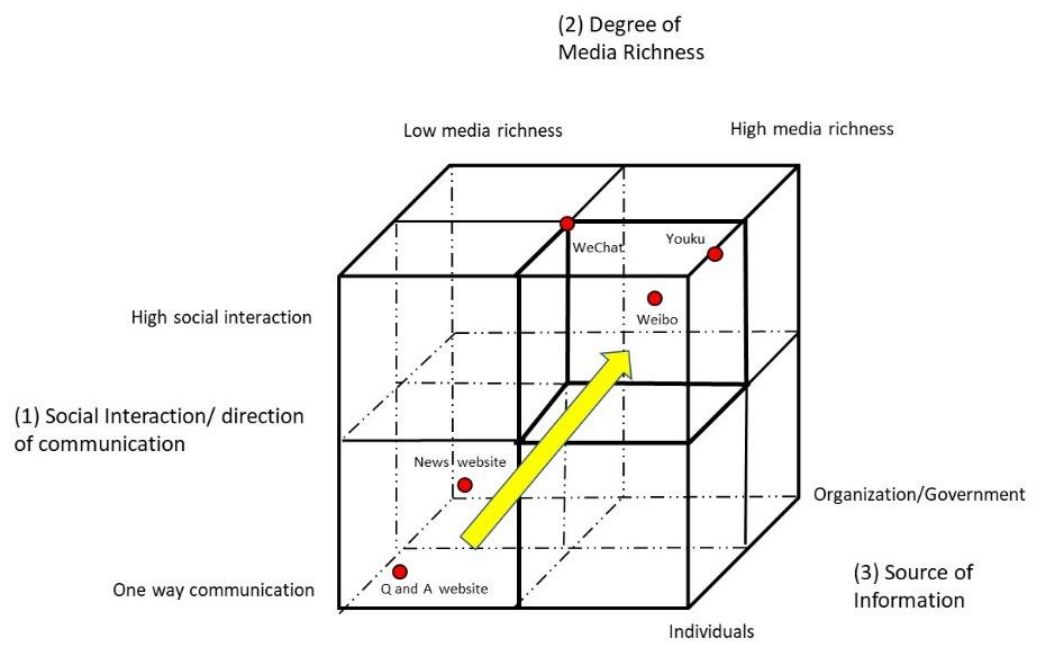

Fig. 2. A roadmap for future online social media use for SCP implementation

To strengthen long term relationships between a city and its stakeholders, it is suggested that platforms with high media richness and high social interaction such as Youku, Weibo and WeChat groups should be utilized. The participative and interactive, nature of these platforms serve as effective channel for city marketing, particularly for implementing a city branding strategy to build city uniqueness and commitment among its audience.

\section{Conclusion}

This article explores the current application of social media use in SCP implementation, and presents an integrated framework of online social media for city branding in China. Compared with traditional media, online social media provides a more participative, and interactive dialogue platform for city stakeholders to voice out their ideas. Despite the fact that microblog and video platforms are very widespread social media categories in china, they have not been fully utilized for city marketing and branding in the case of SCP implementation, implying that government-lead city promotion is still the dominant marketing approach. Although official government website and authoritative news website are fulfilling the purpose of information dissemination, the content is too 
technical for city stakeholders to engage. Future studies should further explore the integration framework of both traditional and online social media in the aspects of city marketing and branding. It is also necessary to conduct a more robust empirical analysis on the mapping of the characteristics content to types of online social media platforms in China.

\section{Acknowledgement}

The research presented in this paper was funded by Institute of Asia Pacific Studies (IAPS) research grant 2019/20- University of Nottingham Ningbo China

\section{References}

1. 10 Most Popular Social Media Sites in China (2019 Updated). https://topdigital.agency/10most-popular-social-media-sites-in-china-2019-updated/ (2019). Accessed 9-5-2020

2. Ashworth, G., Voogd, H.: Selling the City: Marketing Approaches in Public Sector Urban Planning. Belhaven Press, London, UK (1990).

3. Bonakdar, A., Audirac, I.: City Branding and the Link to Urban Planning: Theories, Practices, and Challenges. Journal of Planning Literature 35(2), 2020 (2020).

4. Cao, B.L.: Social media: Definition, history of development, features and future-The ambiguous cognition of social media. Journal of Hunan Radio \& Television University 47(3), 47 (2011).

5. Chan, F.et al. : "Sponge City" in China - a breakthrough of planning and flood risk management in the urban context. Land Use Policy 76(76), 772-228 (2018).

6. Cheung, M.K., Thadani, D.T.: The Impact of Electronic Word-of-Mouth Communication: A Literature Analysis and Integrative Model. Decision Support Systems 54(1), 461-470 (2012).

7. Correa, T., Hinsley, A.W., de Zúñiga, H.G.: Who interacts on the Web?: The intersection of users' personality and social media use. Computers in Human Behavior 26(2), 247253 (2010).

8. Friedmann, J.: The World City Hypothesis. Development and Change 17(1), 69-83 (1986).

9. Guo, G.Q., Liu, Y.P.: The new development of the research on city marketing. Contemporary Economy \& Management 28(2), 5-12 (2006).

10. Harris, J., McKenzie, K., Rentfro, R.: Building trust or mistrust: The search for performance reporting from a citizen's perspective. Journal of Government Financial Management 58(4), 40-46 (2009).

11. Harvey, D.: From Managerialism to Entrepreneurialism: The Transformation in Urban Governance in Late Capitalism. Human Geography 71(1), 3-17 (1989).

12. Harvey, D.: A Brief History of Neoliberalism. Oxford University Press, Oxford, UK (2007).

13. Hernandez, J., Lopez, M.C.: Is there a role for informal settlements in branding cities? The Journal of Place Management and Development 4(1) (2011).

14. Hodge, G.A., Greve, C.: Public-private partnerships: an international performance review. Public Administration Review 67(3), 545-558 (2007). 
15. Jiang, Y.: China's water scarcity. Journal Environmental Management 90(11), 3185-3196 (2009).

16. Kaplan, A.M., Haenlein, M.: Users of the world, unite! The challenges and opportunities of Social Media. Business Horizons 53(1), 59-68 (2009).

17. Kavaratzis, M.: From city marketing to city branding: Towards a theoretical framework for developing city brands. Place Branding 1(1), 58-73 (2004).

18. Kavaratzis, M., Ashworth, G.J.: City branding: An effective assertion of identity or a transitory marketing trick? Tijdschrift voor Economische en Sociale Geografie 96(5), 506-514 (2005).

19. Kotler, P., Asplund, C., Rein, I., Heider, D.: Marketing places Europe: Attracting investments, industries, residents and visitors European cities, communities, regions and nations

Pearson Education, London (1999).

20. Krishnamurthy, S., Dou, W.: Advertising with User- Generated Content: A Framework and Research Agenda. Journal of Interactive Advertising 8(2), 1-7 (2008).

21. Liang, X.: Integrated economic and financial analysis of China's Sponge City Program for water-resilient urban development. Sustainability 10(3) (2018).

22. Liu, H., Jia, Y., Niu, C.: Sponge city" concept helps solve China's urban water problems. Environmental Earth Sciences 76(14) (2017).

23. Mangold, W.G., Faulds, D.J.: Social media: The new hybrid element of the promotion mix. Business Horizons 52(1), 357-365 (2009).

24. MHURD: Sponge city construction in Xiamen has been showing results. http://www.mohurd.gov.cn/dfxx/201608/t20160816_228553.html (2016). Accessed 5-9-2020

25. Qiu, Q.: Role analysis in city marketing. http://www.paper.edu.cn (2005). Accessed 9-8-2020

26. Sadeghi, L. (ed.) Web 2.0. CRC Press, Boca Raton, FL (2012).

27. Sassen, S.: Global Networks, Linked Cities. Routledge, New York

(2016).

28. Searson, E.M., Johnson, M.A.: Transparency laws and interactive public relations: An analysis of Latin American government Web sites. Public Relations Review 36(2), 120-126 (2010).

29. Shao, G.: Understanding the Appeal of User- Generated Media: A Uses and Gratification Perspective. Internet Research(19), 1 (2009).

30. Stockmann, D., Luo, T.: Which Social Media Facilitate Online Public Opinion in China? Problems of Post-Communism 64(3-4), 189-202 (2017).

31. Trueman, M.M., Klemm, M., Giroud, A., Lindley, T.: Bradford in the premier league? A multidisciplinary approach to branding and re-positioning a city. In: Working paper 01/04. Bradford University School of Management, Bradford, UK, (2001).

32. Wang, L.: Marketing in social media era. Management \& Technology of SME 8, 202-203 (2012).

33. Webster, J., Watson, R.T.: Analyzing the Past to Prepare for the Future: Writing a Literature Review. MIS Quarterly 26(2), 13-23 (2002).

34. Wigmo, J., Wikström, E.: Social media marketing: What role can social media play as a marketing tool? , Linnaus University (2010). 
35. Yu, X.: Analysis of brand communication strategies in social media era. The Press 4, 122133 (2011).

36. Zhang, L., Zhao, S.X.B.: City branding and the Olympic effect: A case study of Beijing. Cities. 26(5), 245-254 (2009).

37. Zhang, S., Zevenbergen, C., Rabé, P., Jiang, Y.: The influences of sponge city on property values in Wuhan, China. Water 10(6) (2018).

38. Zhao, Q.S.: The interactive mechanism between city brand and city customers. Modern Economic Research 9, 36-39 (2010).

39. Zhou, L., Wang, T.: Social media: A new vehicle for city marketing in China. Cities 37(C), 27-32 (2014). 